\title{
A REVIEW ON MEDICINAL PLANTS OF RAJASTHAN HAVING ANTIDIABETIC ACTIVITY
}

\author{
CHARUTA MATHUR, GUPTA RS*
}

Department of Zoology, Reproductive Physiology Section, Center for Advanced Studies, University of Rajasthan, Jaipur. Email: gupta_rs@hotmail.com

Received: 09 July 2018, Revised and Accepted: 01 August 2018

ABSTRACT

Diabetes is one of the most common chronic diseases in nearly all countries, and continuously increasing in numbers and significance, as changing lifestyles lead to reduced physical activity. Diabetes is the leading cause of blindness, renal failure, and lower limb amputation. Diabetes is also now one of the leading causes of death, largely because of a markedly increased risk of coronary heart disease and stroke. Due to the existing synthetic drugs have many limitations, the medicine from plants is drawing ever-increasing attention worldwide, due to their low toxicity and few side effects. The present review is providing data of some important medicinal plants species possessing antihyperglycemic and antidiabetic activity. It would provide a handbook for the research related to diabetes. Further, efforts should be made to implement these plants based drugs in clinical trials.

Keywords: Antidiabetic, Antihyperglycemic, Hypolipidemic

(C) 2018 The Authors. Published by Innovare Academic Sciences Pvt Ltd. This is an open access article under the CC BY license (http://creativecommons. org/licenses/by/4. 0/) DOI: http://dx.doi.org/10.22159/ajpcr.2018.v11i12.28176

\section{INTRODUCTION}

Diabetes mellitus (DM) is the most common metabolic disorder characterized by irregulation of carbohydrate, protein, and fat metabolism. It leads to high blood glucose concentration or hyperglycemia and secondary to an absolute or relative lack of the hormone insulin [1]. Insulin unavailability may be due to degenerative changes in $\beta$-cells in the pancreatic islets, reduced effectiveness of the hormones due to the formation of anti-insulin antibodies or inactive complexes, immune-mediated islet cytotoxicity, or inappropriate secretion of hormones by neoplasm in other endocrine organs [2]. Deficiency or insensitivity causes glucose to accumulate in the blood, leading to various complications. Polydipsia, polyphagia, and excessive weight loss occurred due to this. Classification of DM is based on its etiology and clinical presentation. There are four types of DM such as type 1 diabetes, type 2 diabetes, gestational diabetes, and other specific types [3]. Type I diabetes, often referred to as juvenile diabetes, is insulin dependent and known to affect only 5\% of the diabetic population. Type 1 diabetes is said to account for only a minority of the total burden of diabetes in a population although it is the major type of diabetes in younger age groups at majority of well-to-do countries. The incidence of type 1 diabetes is increasing in both rich and poor countries. Type $2 \mathrm{DM}$ accounts for over $85 \%$ of DM worldwide and is associated with a high incidence of morbidity and mortality. It is estimated that 143 million people worldwide suffering from this disease. It has been predicted that the number may probably double by 2030 . With an estimated 50.8 million people living with diabetes, India has the world's largest diabetes population, followed by China with 43.2 million. In 2011, it was reported that one person died from diabetes-related causes every $7 \mathrm{~s}$. Annual global health-care spending on diabetes was up to US $\$ 465$ billion in 2011 (International Diabetes Federation, 2011a). In the management of type 2 DM, lifestyle modification (exercise, weight control, and nutrition) is crucial [4].

At present, available therapy for diabetes includes insulin and a range of oral hypoglycemic agents such as sulfonylureas, metformin, glucosidase inhibitors, and troglitazone. However, these are reported to produce serious adverse side effects such as liver problems, lactic acidosis, and diarrhea [5].

Plants have their chemical compounds which demonstrate alternative and safe effects on DM. The majority of plants contain various phytoconstituents, namely glycosides, alkaloids, terpenoids, flavonoids, carotenoids, etc., that is, frequently implicated as having antidiabetic effect [6]. To date, hundreds of herbs and traditional medicine formulas have been reported to have been used for the treatment of DM. In the past decade, research has been focused on scientific evaluation and justification of traditional drugs of plant origin and screening of more effective and safe antidiabetic potentials has continued to be an important area.

\section{ANTIDIABETIC ACTIVITY OF MEDICINAL PLANTS OF RAJASTHAN}

Rajasthan, the largest state of India exhibits variety in physiognomy, climate, and soil, therefore, the vegetation including a wide variety of medicinal plants. The tribals of remote areas of Rajasthan are totally dependent on indigenous system of medicine for their health as it is difficult for them to get modern medical facilities for their day-to-day health problems. The traditional healers of Rajasthan are having a commendable knowledge of the medicinal intrinsic worth of plants that grow around them [7]. Various ethnobotanical studies carried out in Rajasthan indicate that some plants are being used for their antidiabetic potential by most of the tribals.

Acacia nilotica (Family - Mimosaceae, Local name - Babul, Kikar) It is a moderate-sized tree with a spreading crown. It is indigenous to the Indian subcontinent as also in Tropical Africa, Burma, Sri Lanka, Saudi Arabia, and Egypt, and in West and East Sudan. In India, natural babul forests are generally found in Rajasthan. It contains catechin, gallolyated flavan-3, 4-diol, robidandiol, androstene steroid, d-pinitol carbohydrate, catechin-5-galloyl ester, and gallic, m-digallic, and chlorogenic acids, the plants in the Middle East are also rich in potassium, phosphorus, magnesium, iron, and manganese [8]. A study shows that the leaves extract of this plant has significant hypoglycemic, antioxidant, and hypolipidemic effect. This potential activity of A. nilotica leaf might be due to the presence of its phytochemicals or the collective action of many active ingredients (Fig. 1).

Argemone mexicana L. (Family - Papaveraceae, Local name - Pili kateli/Satayanasi)

It is commonly known as prickly poppy and is an indigenous herb used as a medicinal plant in several parts of Rajasthan. The plant consists of alkaloids, namely berberine, protopine, sarguinarine, optisine, chelerythrine, etc. Medicinal plants being the effective source of both traditional and modern 
medicines are genuinely useful for primary health care. Hypoglycemic and antidiabetic activity of ethanolic and aqueous extracts of whole plants have been reported in normoglycemic and alloxan-induced hyperglycemic rats by single-dose and multi-dose treatment [9] (Fig. 2).

\section{Capparis decidua (Family - Capparidaceae, Local name - Kair)}

C. decidua is the native plant of Thar desert. The plant is xerophytic and drought resistant; belongs to family Capparidaceae. The genus Capparis comprises 250 species including trees, shrubs, and woody climbers, but in India, only 26 species of the genus are reported $[10,11]$ commonly known as teent in Rajasthan. The plant is rich in nutrient, used for nutraceutical purposes by local people. Young berries are used to make pickle and vegetable [12]. The plant is an important component of desert ecosystem. Various phytoconstituents have been isolated from C. decidua. Various phytoconstituent have been isolated from C. decidua such as $\beta$-sitosterol, spermidine alkaloid, isocodonocarpine, Capparine, Cappariline, Capparinine are isolated from root $[10,13]$. Ethanolic extract of aerial part of the plant showed anti-inflammatory and analgesic activity. Fruits have antidiabetic, hypolipidemic, antiatherosclerotic, and antihypertensive activities. Alcoholic extract obtained from bark, flower, and fruit showed hypolipidemic activity in model rat (Fig. 3).

Catharanthus roseus (Family - Apocynaceae, Local name - Rose periwinkle)

Catharanthus is commonly used in most of the herbal preparations for diabetes. It has been reported to consist of anticancer activity [14], antidiabetic activity (flowers and leaves) [15], hypolipidemic activity [16], and antioxidant activity [17]. The main phytoconstituents present in this plant are alkaloids [14], flavonoids [18], and steroids [19]. It has been used effectively in various traditional systems of medicines for the treatment of diabetes. Catharanthine is the major active phytoconstituents in C. roseus that shows antidiabetic activity (Fig. 4).

Datura inoxia Mill. (Family - Solanaceae, Local name - Dhatura)

It is a low growing, spreading perennial with hairy $2-5 \mathrm{in}$. leaves, white flowers, and a spiny fruit plant. This plant conquers a very special place in Ayurveda since all plant parts, namely flowers, leaves, root, stem, fruit, and seeds, have been meritoriously employed for a range of treatments such as insanity, rabies, and leprosy. D. inoxia includes atropine, scopolamine hyoscyamine, with an olides (lactones) and other tropanes. Leaf extracts show flavonoids, phenolic compounds, cardiac glycosides, and sugars, and the formation of the $\mathrm{Fe}_{3} \mathrm{O}_{4}$ nanoparticles was first monitored using UV-Vis absorption spectroscopy typical surface plasma absorption maxima at 270-290 nm. Seed extracts of D. inoxia have the strongest antioxidant potential [20] (Fig. 5).

\section{Morus alba (Family - Moraceae, Local name - White mulberry)}

It is usually a short-lived plant native to north China. Moracin M, steppogenin- $4^{\prime}-0-\beta$-D-glucoside, and mulberroside A were isolated from the root bark of $M$. alba L. These all produced hypoglycemic effects [21]. Hypolipidemic and antioxidant effects from freeze-dried powder of mulberry (M. alba L.) fruit are also investigated [22]. Mulberroside A, a glycosylated stilbenoid, can be useful in the treatment of hyperuricemia and gout $[23,24]$. An ethanolic extract of mulberry leaf has antihyperglycemic, antioxidant, and antiglycation effects in chronic diabetic rats [25] (Fig. 6).

Pterocarpus marsupium (Family - Fabaceae, Local name - Indian Kino Tree)

Pterocarpus is a genus of pantropical trees. The diseases commonly treated by Pterocarpus in the Ayurveda system are diabetes, inflammation, and bleeding. The bark of plant is also useful for bleeding and toothaches. The leaves are often applied externally as a remedy for skin diseases ethyl acetate extract of root contains benzofuranone, marsupium stilbene, pterostilbene, etc., marsupium and pterostilbene significantly lower the blood glucose levels useful in diabetic rats while pterostilbene acts as hypolipidemic, hypoglycemic, significant reduction in glycosylated $\mathrm{Hb}$, and increase in total $\mathrm{Hb}$ level. The wooden glass made up of heartwood of $P$. marsupium is being used for drinking water to control blood sugar and strong antidiabetic in Ayurvedic system of medicine. Heartwood of P. marsupium has been examined clinically and found efficient in insulinindependent DM patients (type 2 DM) [26] (Fig. 7).

Tinospora cordifolia (Family - Menispermaceae, Local name - giloy) T. cordifolia is a shrub that is native to India. Its root, stems, and leaves are used in Ayurvedic medicine. It is used for diabetes, high cholesterol, allergic rhinitis (hay fever), upset stomach, gout, lymphoma and other cancers, rheumatoid arthritis, hepatitis, peptic ulcer disease, fever, gonorrhea, syphilis, and to boost the immune system. T. cordifolia is the major sources

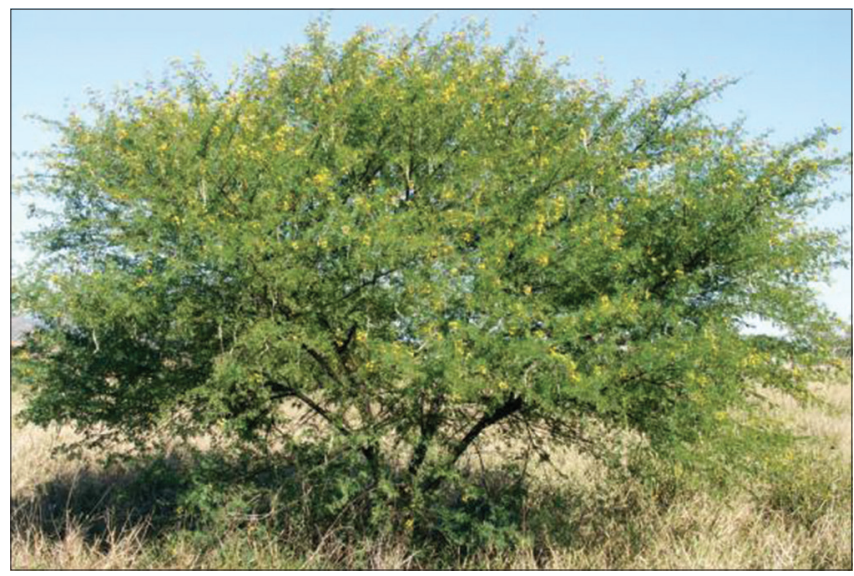

Fig. 1: Acacia nilotica

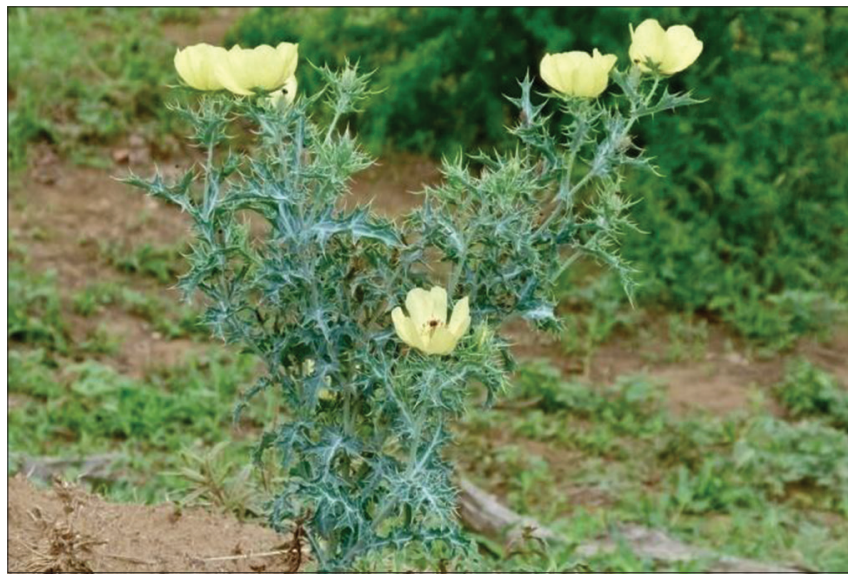

Fig. 2: Argemone mexicana $L$

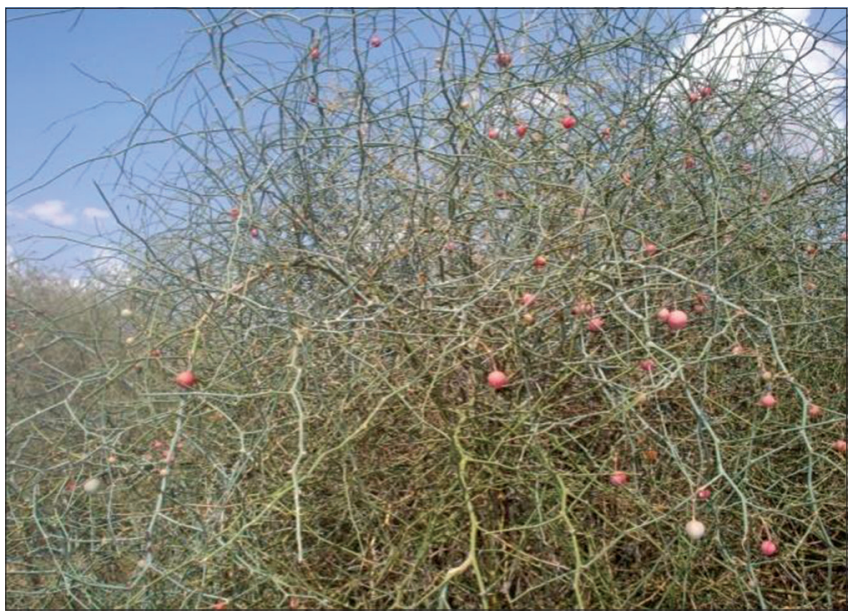

Fig. 3: Capparis decidua 


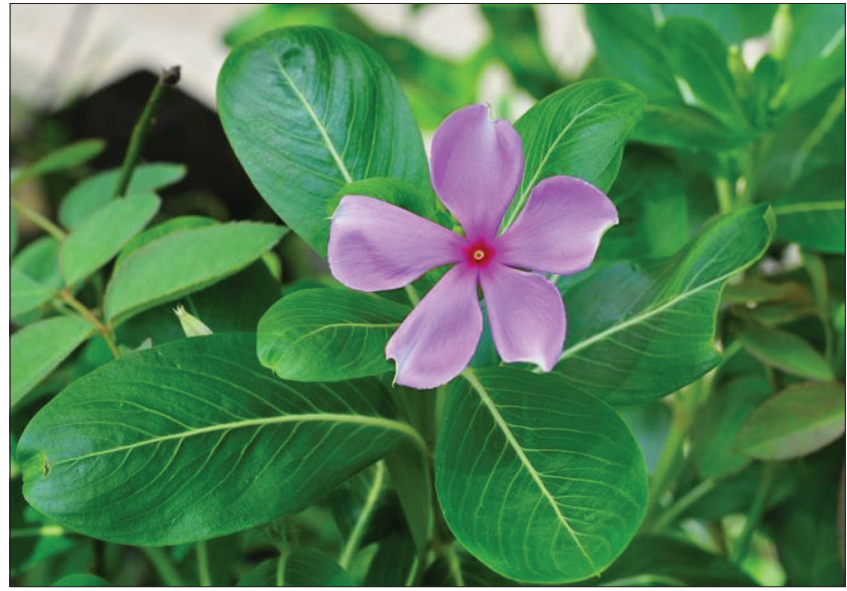

Fig. 4: Catharanthus roseus

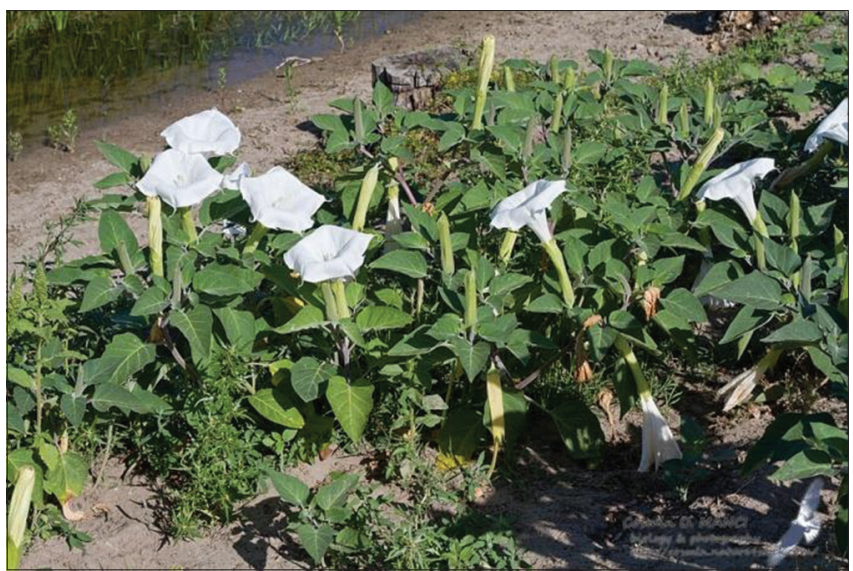

Fig. 5: Datura inoxia Mill.

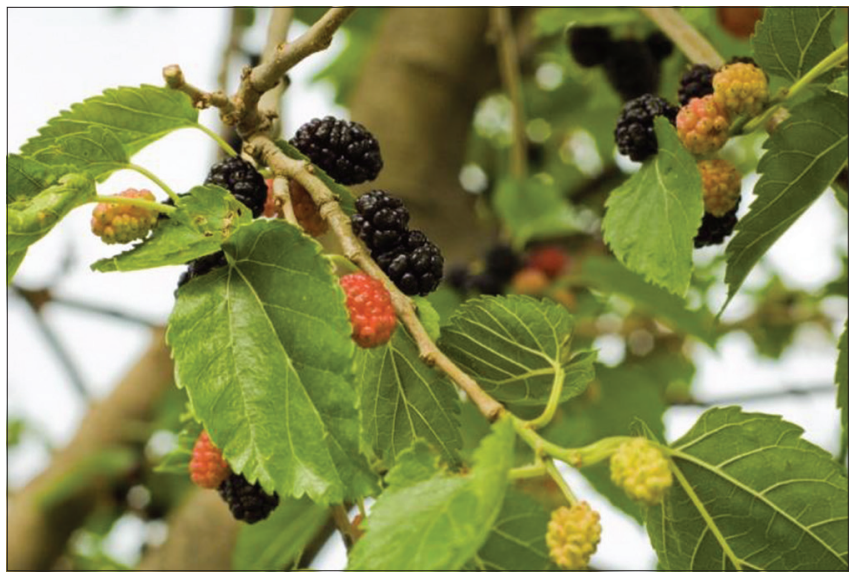

Fig. 6: Morus alba

of tinosporine, cordifolide, tinosporide, cordifole, and columbin that regulate cholesterol synthesis and glycolysis [27-29] (Fig. 8).

Tridax procumbens Linn. (Family - Asteraceae, Local name - Rukhari) It is a species of flowering plant in the daisy family. It is best known as a widespread weed and pest plant. It has been extensively used in Indian traditional medicine as anticoagulant, antifungal and insect repellent, in bronchial catarrh, diarrhea, and dysentery. Moreover, it comprises wound remedial activity and promotes hair growth. It is also

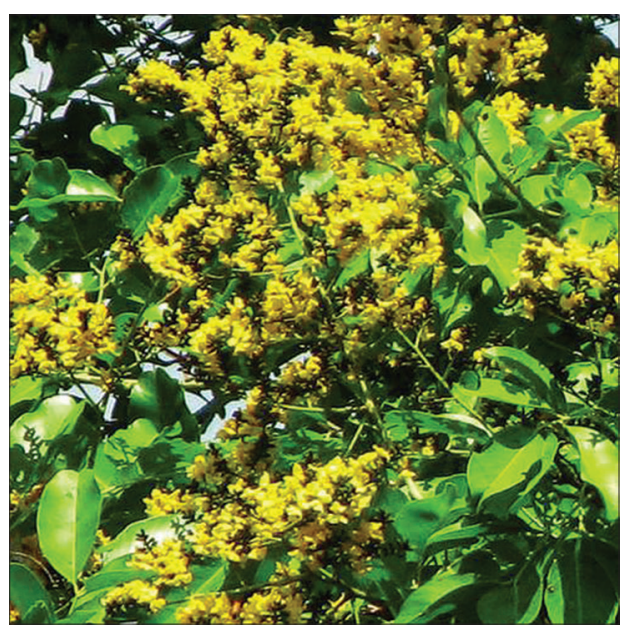

Fig. 7: Pterocarpus marsupium

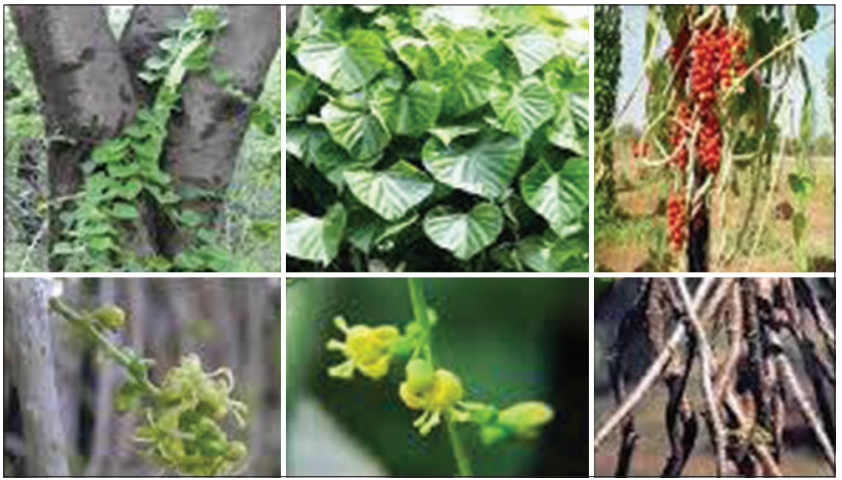

Fig. 8: Tinospora cordifolia

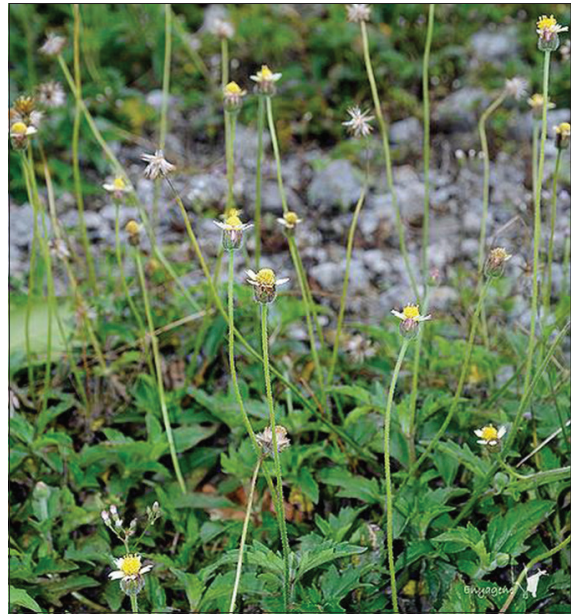

Fig. 9: Tridax procumbens Linn.

diverse as Bhringraj, which is well-known Ayurvedic medicine for liver disorders [30]. Antioxidant properties [31] of this plant have also been demonstrated (Fig. 9).

Xanthium strumarium Linn. (Family - Asteraceae, Local name - AadhaShishi)

This plant is a summer annual that becomes about 2-4' tall. The aerial parts of the plant contain a mixture of unidentified alkaloids, sesquiterpene lactones, namely xanthinin, xanthatin, and xanthosine, guaianolides, germacranolides, and elemanolides, sulfated, glycoside, 
Table 1: Plants with antidiabetic activity

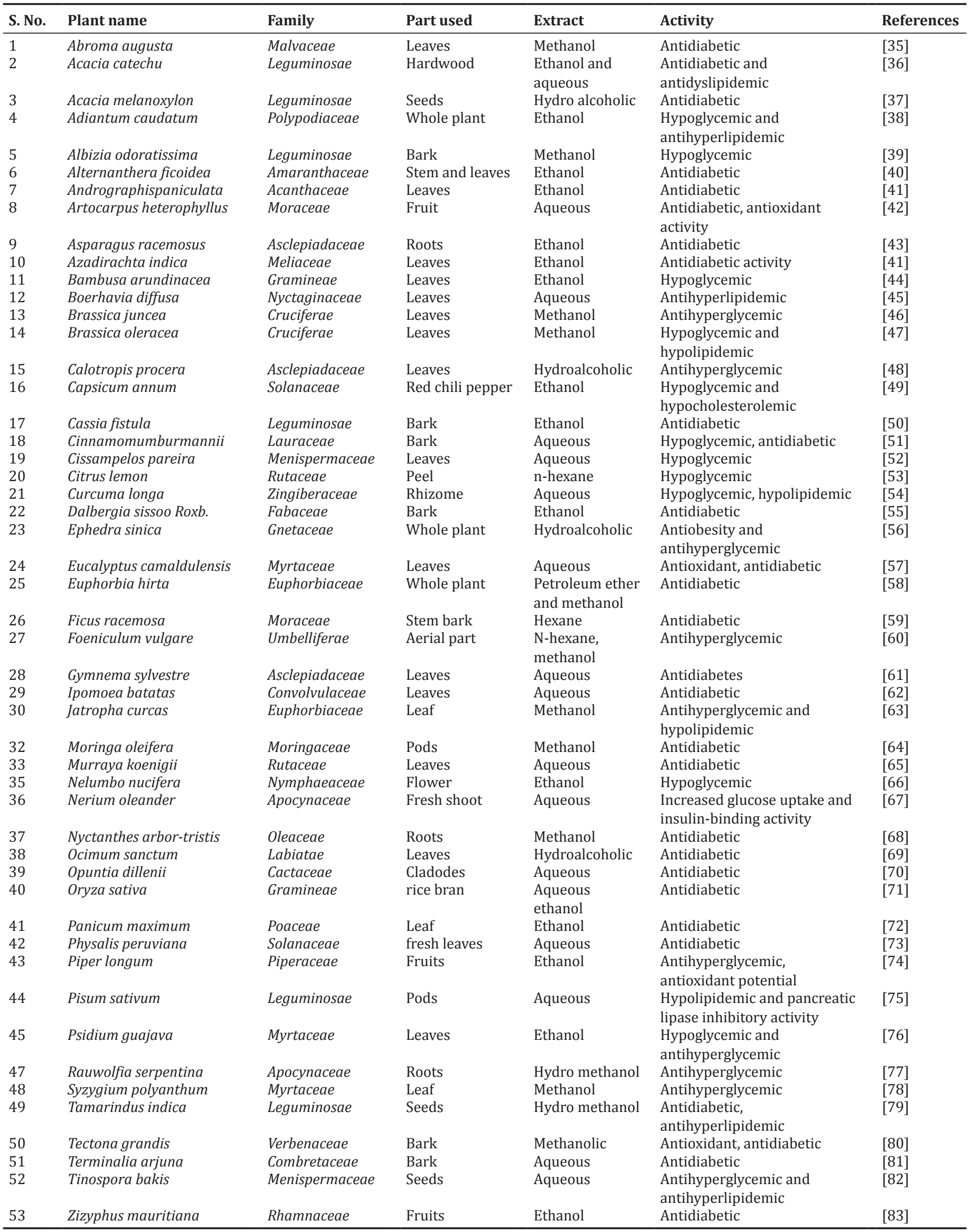




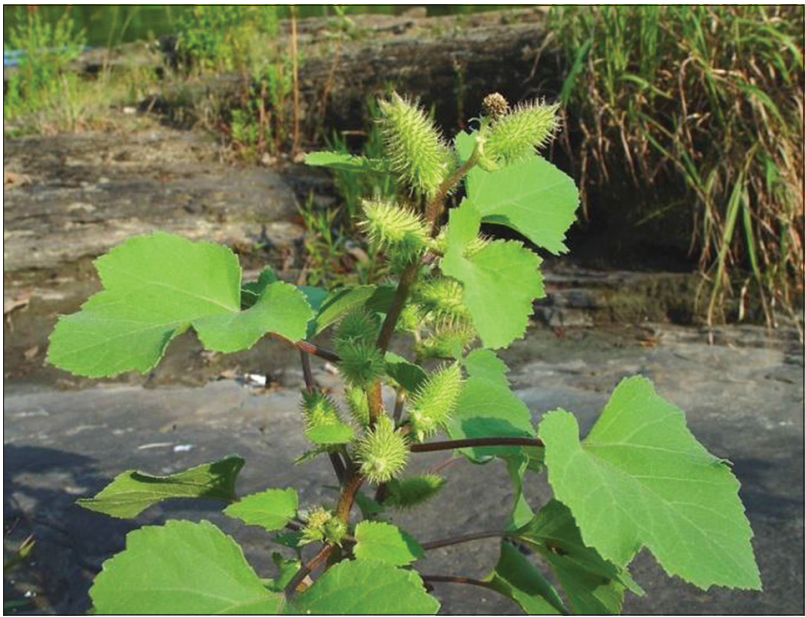

Fig. 10: Xanthium strumarium Linn.

xanthostrumarin, atractyloside, and carboxyatractyloside. Fruits are rich in Vitamin C. This plant is found to possess diverse biological activities including antibacterial, antifungal, antimalarial, anti-rheumatic, antispasmodic, antitussive, cytotoxic, hypoglycemic, stomachic, tonic, diuretic, sedative, allergic rhinitis, sinusitis, urticaria, constipation, diarrhea, lumbago, leprosy, and pruritis [32,33]. The acetone extract of fruits of $X$. strumarium $\mathrm{L}$. is reported to have antidiabetic activity due to the presence of phenolic compounds [34] (Fig. 10).

Plants listed above also have been reported with antioxidant, antihyperglycemic, and hypoglycemic effects which may be important in the management of diabetes (Table 1).

\section{CONCLUSION}

This review reports the advantages of herbal drugs over the synthetic drugs. Major fraction of the plants listed above has been reported with antioxidative and antihyperglycemic effect which may be important in the management of these diseases. The result of this review can be helpful for the drug industry to study on the components of these herbs and investigate further to find a component with higher efficacy. Further, well-designed clinical trials are still needed to focus on safe and cost-effective herbal products.

\section{AUTHORS' CONTRIBUTION}

Charuta Mathur: The main author is doing her thesis on "antidiabetic activity of methanolic crude extract of Capparis decidua in male albino rats." Dr. R.S Gupta: Corresponding author is the supervisor of main author. He has been working as Associate Professor in the Department of Zoology, University of Rajasthan. He has been involved in various projects of antifertility and antidiabetic activity of various plant extracts.

\section{CONFLICTS OF INTEREST}

There are no conflicts of interest in the submitted review article.

\section{REFERENCES}

1. Okon JE, Ofeni AA. Antidiabetic effect of Dioscorea bulfifera on alloxan-induced diabetic rats. CIB Tech J Pharm Sci 2013;1:14-9.

2. Sachan NK, Kumar Y, Pushkar S, Thakur RN, Gangwar SS, Kalaichelvan VK, et al. Antidiabetic potential of alchohol and aqueous extracts of Ficus racemosa Linn. Bark in normal and alloxan-induced diabetic rats. Int J Pharm Sci Drug Res 2009;1:24-7.

3. Sicree R, Shaw J, Zimmet P. The global burden. diabetes and impaired glucose tolerance. prevalence and projections. In: Gan D, editor. Diabetes Atlas. $3^{\text {rd }}$ ed. Brussels: International Diabetes Federation; 2006. p. 16-103.

4. Matheka DM, Alkizim FO. Complementary and alternative medicine for Type 2 diabetes mellitus: Role of medicinal herbs. J Diabetes Endocrinol 2012;3:44-56.

5. Khan A, Anderson RA. Insulin potentiating factor (IPF) present in foods, species and natural products. Pak J Nutr 2003;2:254-7.

6. Malviya N, Jain S, Malviya S. Antidiabetic potential of medicinal plants. Acta Pol Pharm 2010;67:113-8.

7. Jain A, Katewa SS, Galav P, Nag A. Some therapeutic uses of biodiversity among the tribals of Rajasthan. Indian J Tradit Knowl 2008; 7:256-62.

8. Pareek P, Choudhry M. Management of Type 2 diabetics by Indian gum Arabic (Acacia nilotica) pods powder. Int J Food Nutr Sci 2013;2:77-83.

9. Nayak P, Kar DM, Maharana L. Antidiabetic activity of aerial parts of Argemone mexicana L. In alloxan induced hyperglycaemic rats. Pharmacol Online2011;1:889-903.

10. Rathee S, Rathee P, Rathee D, Rathee D, Kumar V. Phytochemical and pharmacological potential of kair (Capparis decidua). Int J Phytomed 2010;2:7-10.

11. Singh D, Singh RK. Kair (Capparis decidua): A potential ethnobotanical weather predictor and livelihood security shrub of the arid zone of Rajasthan and Gujarat. Indian J Tradit Knowl 2011;10:146-55.

12. Upadhyay RK. Kareelplant: A natural source of medicines and nutrients. Int J Green Pharm (IJGP) 2011;5:255-65.

13. Verma PD, Dangar RD, Shah KN, Gandhi DM, SuhagiaBN. Pharmacognostical potential of Capparis deciduas Edgew. J Appl Pharm Sci 2011;1:6-11.

14. Jean HR, Jean MN, Gaelle LC, Philippe T, Monique ZH, Louisette LM, et al. Isolation of indole alkaloids from Catharanthus roseus by centrifugal partition chromatography in the $\mathrm{pH}$-zone refining mode. J Chromatogr A 1999;849:421-31.

15. Sumana G, Suryawanshi SA. Effect of Vinca rosea extracts in treatment of alloxan diabetes in male albino rat. Indian J Exp Biol 2001;39:748-59.

16. Antia BS, Okokon JE. Effect of leaf juice of Catharanthus roseus Linn. On cholesterol, triglyceride and lipoproteins levels in normal rats. Indian J Pharm 2005;37:401-2.

17. Jaleel CA, Gopi R, Manivannan P, Sankar B, Kishorekumar A, Panneerselvam R, et al. Antioxidant potentials and ajmalicine accumulation in Catharanthus roseus after treatment with giberellic acid. Colloids Surf B Biointerfaces 2007;60:195-200.

18. Gilles B, Marie GD, Bruno D, Anne MM. A new flavonol glycoside from Catharanthus roseus. Phytochemistry 1999;50:167-9.

19. Akirai S. Brassinosteroid biosynthesis. Plant Physiol Biochem 1999;37:351-61.

20. Ramadan MF, Zayed R, El-Shamy H. Screening of bioactive lipids and radical scavenging potential of some Solanaceae plants. Food Chem 2007:103:885-90.

21. Zhang M, Chen $\mathrm{M}$, Zhang $\mathrm{HQ}$, Sun $\mathrm{S}, \mathrm{Xia} \mathrm{B}, \mathrm{Wu} \mathrm{FH}$, et al. In vivo hypoglycemic effects of phenolics from the root bark of Morus alba. Fitoterapia 2009;80:475-7

22. Yang X, Yang L, Zheng H. Hypolipidemic and antioxidant effects of mulberry (Morus alba L.) fruit in hyperlipidaemia rats. Food Chem Toxicol 2010;48:2374-9.

23. Wang CP, Wang Y, Wang X, Zhang X, Ye JF, Hu LS, et al. Mulberroside a possesses potent uricosuric and nephroprotective effects in hyperuricemic mice. Planta Med 2011;77:786-94.

24. Kim JK, Kim M, Cho SG, Kim MK, Kim SW, Lim YH, et al. Biotransformation of mulberroside a from Morus alba results in enhancement of tyrosinase inhibition. J Ind Microbiol Biotechnol 2010;37:631-7.

25. Naowaboot J, Pannangpetch P, Kukongviriyapan V, Kongyingyoes B, Kukongviriyapan U. Antihyperglycemic, antioxidant and antiglycation activities of mulberry leaf extract in streptozotocin-induced chronic diabetic rats. Plant Foods Hum Nutr 2009;64:116-21.

26. Flexible Dose Open trial of Vijayasar in Cases of Newly-Diagnosed Non-insulin-Dependent Diabetes Mellitus. Indian council of medical research (ICMR), collaborating centres, New Delhi. Indian J Med Res 1998;108:24-9.

27. Hui H, Tang G, Go VL. Hypoglycemic herbs and their action mechanisms. Chin Med 2009;4:11.

28. Kar A, Choudhary BK, Bandyopadhyay NG. Comparative evaluation of hypoglycaemic activity of some Indian medicinal plants in alloxan diabetic rats. J Ethnopharmacol 2003;84:105-8.

29. van de Venter M, Roux S, Bungu LC, Louw J, Crouch NR, Grace OM, et al. Antidiabetic screening and scoring of 11 plants traditionally used in South Africa. J Ethnopharmacol 2008;119:81-6.

30. Pathak AK, Saraf S, Dixit VK. Hepatoprotective activity of Tridax procumbens-Part I. Fitoterapia 1991;62:307-13.

31. Ravikumar V, Shivashangari KS, Devaki T. Effect of Tridax procumbens 
on liver antioxidant defense system during lipopolysaccharide-induced hepatitis in D-galactosamine sensitised rats. Mol Cell Biochem 2005;269:131-6.

32. Chopra RN, Nayar SL, Chopra IC. Glossary of Indian Medicinal Plants. New Delhi: Council of Scientific and Industrial Research; 1945. p. 259.

33. Moerman D. Native American Ethnobotany. Oregon. Portland: Timber Press; 1998. p. 453-9.

34. AgarwalA. Critical issues in quality control of herbal products. Pharm Times 2005;37:9-11.

35. Khanra R, Dewanjee S, K Dua T, Sahu R, Gangopadhyay M, De Feo V, et al. Abroma augusta L. (Malvaceae) leaf extract attenuates diabetes induced nephropathy and cardiomyopathy via inhibition of oxidative stress and inflammatory response. J Transl Med 2015;13:6.

36. Srivastava SP, Mishra A, Bhatia V, Tadigoppula N, Srivastava AK. Acacia catechu hard wood: Potential anti-diabetic cum antidyslipidemic. Med Chem Res 2011;20:1732-9.

37. Kumar S, Chodhary M, Yadav P, Nitesh N, Budhawar V. Anti-diabetic activity of hydroalcoholic extract of Acacia melanoxylon Linn. Seeds in streptozotocin induced diabetic rats. J Diabetes Res Ther 2016;2:3.

38. Saha D, Ghosh SK, Das T, Mishra SB. Hypoglycemic and antihyperlipidemic effects of Adiantum caudatum in alloxan induced diabetes in rats. Asian J Pharm Clin Res 2016;9:361-3.

39. Kumar D, Kumar S, Kohli S, Arya R, Gupta J. Antidiabetic activity of methanolic bark extract of Albizia odoratissima Benth. In alloxan induced diabetic albino mice. Asian Pac J Trop Med 2011;4:900-3.

40. Rajan TS, Aanandhi VM. Antidiabetic activity of ethanolic extract of Alternanthera ficodia Linn in streptozotocin induced diabetic rats. Int J Pharm Bio Sci 2016;7:177-80.

41. Akter R, Mahabub-Uz-Zaman M, Rahman MS, Khatun MA, Abdullah AM, Ahmed NU, et al. Comparative studies on antidiabetic effect with phytochemical screening of Azadirachta indicia and Andrographis paniculata. IOSR J Pharm Biol Sci 2013;5:122-8.

42. Biworo A, Tanjung E, Iskandar R, Khairina S, Suhartono E. Antidiabetic and antioxidant activity of jackfruit (Artocarpus heterophyllus) extract. J Med Bioeng 2015;4:318-23.

43. Hannan JM, Marenah L, Ali L, Rokeya B, Flatt PR, Abdel-Wahab YH, et al. Insulin secretory actions of extracts of Asparagus racemosus root in perfused pancreas, isolated islets and clonal pancreatic b-cells. J Endocrinol 2007;192:159-68.

44. Nazreen S, Kaur G, Alam MM, Haider S, Hamid H, Alam MS, et al. Hypoglycemic activity of Bambusa arudiacea leaf ethaolic extract in streptozotocin induced diabetic rats. Pharmacol Online 2011;1:964-72.

45. Kanagavalli U, Bhuvaneshwari B, Sadiq AM. Antidiabetic activity of Boerhaavia diffusa against alloxan induced diabetic rats. Int J Pharm Bio Sci 2015;6:1215-9.

46. Rahmatullah M, Shefa TF, Hasan L, Hossain MT, Ahmed S, Mamun AA, et al. A study on antinociceptive and anti-hyperglycemic activity of methanol extract of Brassica juncea Linn. Czern. Leaves in mice. Adv Nat Appl Sci 2010;4:221-5.

47. Assad T, Khan RA, Feroz Z. Evaluation of hypoglycemic and hypolipidemic activity of methanol extract of Brassica oleracea. Chin J Nat Med 2014;12:648-53.

48. Neto MC, de Vasconcelos CF, Thijan VN, Caldas GF, Araújo AV, CostaSilva JH, et al. Evaluation of antihyperglycaemic activity of Calotropis procera leaves extract on streptozotocin-induced diabetes in wistar rats. Rev Bras Farmacogn 2013;23:913-9.

49. Magied MM, Salama NA, Ali MR. Hypoglycemic and hypocholesterolemia effects of intragastric administration of dried red chili pepper (Capsicum annum) in alloxan-induced diabetic male albino rats fed with high-fat-diet. J Food Nutr Res 2014;2:850-6

50. Malpani SN, Manjunath KP, Sholapur H, Savadi RV, Akki KS, Darade SS, et al. Antidiabetic activity of Cassia fistula Linn. Bark in alloxan induced diabetic rats. Int J Pharm Sci 2010;2:382-5.

51. Cheng DM, Kuhn P, Poulev A, Rojo LE, Lila MA, Raskin I, et al. In vivo and in vitro antidiabetic effects of aqueous cinnamon extract and cinnamon polyphenol-enhanced food matrix. Food Chem 2012;135:2994-3002.

52. Piero NM, Eliud NM, Susan KN, George OO, David NJ, Sakyi AD, et al. In vivo antidiabetic activity and safety in rats of Cissampelos pareira traditionally used in the management of diabetes mellitus in Embu county, Kenya. J Drug Metabol Toxicol 2015;6:180.

53. Akhila S, Bindu AR, Bindu K, Aleykutty NA. Phytochemical and pharmacological evaluation of Citrus limon peel. World J Pharm Pharm Sci 2015:4:1128-30.

54. Olatunde A, Joel EB, Tijjani H, Obidola SM, Luka CD. Anti-diabetic activity of aqueous extract of Curcuma longa (Linn) rhizome in normal and alloxan-induced diabetic rats. Researcher 2014;6:58-65.
55. Pund KV, Vyawahare NS, Gadakh RT, Murkute VK. Antidiabetic evaluation of Dalbergia Sissoo against alloxan induced diabetes mellitus in wistar albino rats. J Nat Prod Plant Resour 2012;2:81-8.

56. Song MK, Um JY, Jang HJ, Lee BC. Beneficial effect of dietary Ephedra sinica on obesity and glucose intolerance in high-fat diet-fed mice. Exp Ther Med 2012;3:707-12.

57. Basak SS, Candan F. Chemical composition and in vitro antioxidant and antidiabetic activities of Eucalyptus Camaldulensis Dehnh. Essential oil. J Iran Chem Soc 2010;7:216-26.

58. Devi S, Kumar M. In-vivo antidiabetic activity of methanolic extract of Euphorbia hirta L. Int J Diabetes Endocrinol 2017;2:36-9.

59. Nasution R, Marianne M, Kausar A. Antidiabetic activity of ARA (Ficus racemosa) from ACEH. Int J Chem Tech Res 2010;10:9-10.

60. Mhaidat NM, Abu-zaiton AS, Alzoubi KH, Alzoubi W, Alazab RS. Antihyperglycemic properties of Foeniculum vulgare Extract in streptozotocin- induced diabetes in rats. Int $\mathrm{J}$ Pharmacol 2015;11:72-5

61. El Shafey AA, El-Ezabi MM, Seliem MM, Ouda HH, Ibrahim DS. Effect of Gymnema sylvestre R.Br. Leaves extract on certain physiological parameters of diabetic rats. J King Saud Univ Sci 2013;25:135-41.

62. Ogunrinola OO, Fajana OO, Olaitan SN, Adu OB, Akinola MO. Anti-diabetic activity of Ipomoea batatas Leaves extract: Effects on hepatic enzymes in alloxan-induced diabetic rats. Res J Med Plant 2015;9:227-33

63. Johnson M, Olufunmilayo LA, Adegboyega CC, Adetayo OM. Evaluation of antidiabetic and the effect of methanolic leaf extract of Jatropha curcas on some biochemical parameters in alloxan induced diabetic male albino rats. Eur J Med Plants 2014;4:1501-12.

64. Gupta R, Mathur M, Bajaj VK, Katariya P, Yadav S, Kamal R, et al. Evaluation of antidiabetic and antioxidant activity of Moringa oleifera in experimental diabetes. J Diabetes 2012;4:164-71.

65. Al-Ani IM, Santosa RI, Yankuzo MH, Saxena AK, Alazzawi KS. The antidiabetic activity of curry leaves "Murraya koenigii" on the glucose levels, kidneys, and islets of Langerhans of rats with streptozotocin induced diabetes. Makara J Health Res 2017;21:54-60

66. Sakuljaitrong S, Buddhakala N, Chomko S, Talubmook C. Effects of flower extract from lotus (Nelumbo nucifera) on hypoglycemic and hypolipidemic in streptozotocin-induced diabetic rats. Int J Sci Eng Res 2013;4:1441-6.

67. Fartyal M. Nerium oleander Linn. In vitro alpha amylase inhibitory potential of stem and root extracts. Int J Curr Pharm Res 2017:9:37-41.

68. Sharma V, Marwaha AP. Hypoglycemicactivity of methanolic extracts of Nyctanthes arbor-tristis Linn. Root in alloxan induced diabetic rats. Int J Pharm Pharm Sci 2011:3:210-2.

69. Malairaman U, Mehra V, Sharma A, Khailkhura P. Antioxidant, antiinflammatory, and antidiabetic activity of hydroalcoholic extract of Ocimum sanctum: An in-vitro and in-silico study. Asian J Pharm Clin Res 2016;9:44-9.

70. Zhao LY, Lan QJ, Huang ZC, Ouyang LJ, Zeng FH. Antidiabetic effect of a newly identified component of Opuntia dillenii polysaccharides. Phytomedicine 2011;18:661-8.

71. Shimoda H, Aitani M, Tanaka J, Hitoe S. Purple rice extract exhibits preventive activities on experimental diabetes models and human subjects. J Rice Res 2015;3:137.

72. Antia BS, Okokon JE, Umoh EE, Udobang JA. Antidiabetic activity of ethanolic leaf extract of Panicum maximum. Int J Drug DevRes 2010;2:488-92.

73. Kasali FM, Kadima JN, Mpiana PT, Ngbolua K, Tshibangu DS. Assessment of antidiabetic activity and acute toxicity of leaf extracts from Physalis peruviana L. In guinea-pig. Asian Pac J Trop Biomed 2103;3:841-6

74. Kumar S, Sharma S, Jitpal S. In vivo anti-hyperglycemic and antioxidant potential of Piper longum fruit. J Pharm Res 2011;4:471-4.

75. Inagaki K, Nishimura Y, Iwata E, Manabe S, Goto M, Ogura Y, et al. Hypolipidemic effect of the autoclaved extract prepared from pea (Pisum sativum L.) pods in vivo and in vitro. J Nutr Sci Vitaminol (Tokyo) 2016;62:322-9.

76. Godebo A, Makonnen E, Mekonnen N. Hypoglycemic and antihyperglycemic effect of leaves extracts of Psidium guajava in normoglycemic and streptozotocin-induced diabetic mice. Int J Pharm 2017;4:250-6.

77. Azmi MB, Qureshi SA. Glucose lowering potential of hydromethanolic extract of Rauwolfia serpentine benth, improves the glycemic, antiatherogenic, and cardioprotective indices in alloxan-induced diabetic mice. World J Pharm Sci 2014;2:219-23

78. Widyawati T, Yusoff NA, Asmawi MZ, Ahmad M. Antihyperglycemic 
effect of methanol extract of Syzygium polyanthum (Wight.) leaf in streptozotocin-induced diabetic rats. Nutrients 2015;7:7764-80.

79. Al-Ahdab MA. Anti-hyperglycemic effect of Tamarindus indica extract in streptozotocin-induced diabetes in male rats. World Appl Sci J 2015;33:1940-8

80. Krishnasamy R. Antioxidant and antidiabetic activity of Tectona grandis Linn. In alloxan induced albino rats. Asian J Pharm Clin Res 2013;6 Suppl 3:1974-7.

81. Thomson HA, Ojo OO, Flatt PR, Abdel-Wahab YH. Aqueous bark extracts of Terminalia arjuna stimulates insulin release, enhances insulin action and inhibits starch digestion and protein glycation in vitro. Austin J Endocrinol Diabetes 2014;1:1001.

82. Alamin MA, Yagi AI, Yagi SM. Evaluation of antidiabetic activity of plants used in Western Sudan. Asian Pac J Trop Biomed 2015;5:395-402.

83. Stoilova I, Trifonova D, Marchev A, Stanchev V, Angelova G, Krastanov A. Phytochemical constituents and in vitro anti-diabetic properties of Ziziphus jujuba (Rhamnaceae) Fruits. Int J Pharm Phytochem Res 2017;9:150-8 